\title{
Women, Civil War and Struggle for Survival: A Study of Tamil Women in Ampara District of Sri Lanka
}

\author{
Athula Withanawasam \\ Department of Political Science, Faculty of Arts, \\ University of Peradeniya, \\ Peradeniya 20400, Sri Lanka \\ E-mail: withanawasam@gmail.com
}

Received: May 1, 2021 Accepted: June 2, $2021 \quad$ Published: June 16, 2021

doi:10.5296/ijssr.v9i2.18755 URL: https://doi.org/10.5296/ijssr.v9i2.18755

\begin{abstract}
Even though the civil war in Sri Lanka officially ended in 2009, the hardship created by war is long-lasting and will take years to reconcile. This research is about the impact of war politics on women of Tamil community in the Ampara district of Sri Lanka during the period of armed conflict. The findings of this study reveal that the girls of the Tamil community were forcefully recruited to join the Tamil militant groups. Hence, parents found the only way to rescue their children and to assure their existence was to arrange teenage marriages. Most of those marriages were not legally registered. This paved the way for the male partners to abandon their spouses, often with children. The women whose children were forcefully recruited to militant forces and whose life was lost in the battle filed were given the dignity of 'Veera Thai' (Heroine Mother) with an allowance as gratitude for bearing such a war hero. However, it was revealed the title itself had resulted in many types of hardships. The government also deliberately denied any public assistance to those families. The study has found that the women in the numerically weakest groups during war time, irrespective of age difference, had undergone many and varied hardship. The study further has identified that the hardship experienced by these women continued even in the post-civil war context. Therefore, the study urges that these types of hardship faced by women in the post-war context need to be handled with political sensitivity to the equity and justice for women.
\end{abstract}

Keywords: Civil war, Women of Tamil community, War politics, War hardship, Ampara District, Sri Lanka. 


\section{Introduction}

Women play key roles in economic, social and family life. However, they are the most vulnerable victims of any kind of social and economic issues including ethnic conflict and civil war and the related impact. This study is about the hardship faced by the women of minority Tamil community during the time of war and their continuity after the ending of the civil war with a particular focus on Ampara district in the Eastern province of Sri Lanka. Sri Lanka experienced a bitter civil war based on ethnic identities and divisions nearly three decades. The voluminous literature on Sri Lankan civil war has only made passing remarks on the hardship faced by women during the war time and the continuity of hardship after the end of civil war. They have failed to deeply analyze ad understand the nature and dynamics of hardship faced by the women in war context. This implies that there is no adequate study of this dimension of the impact of war-war hardship faced by women-in Sri Lankan context. The major thrust of this study was to fill the above gap in the literature.

\section{Methodology of the Study}

This study belongs to the tradition of exploratory research. Consequently, no attempt was made to test hypotheses. The objective of the research was to understand the nature and the content of war politics on the hardship faced by Tamil women. The study location is the Ampara district of the Eastern province of Sri Lanka. The Eastern province comprises three administrative districts, namely that of Ampara, Trincomalee and Batticaloa. In the Batticaloa district, Tamils form the majority. In the Trincomalee district, Tamils forms the second majority. In Ampara district, the Tamils become the third ethnic community in terms of numerical strength. However, Tamils form the first majority in the entire Eastern province. The specificity of the Eastern province is that it is one of the provinces in Sri Lanka which has no single community forming an absolute majority.

The study location was deliberately chosen on the following grounds. Firstly, Ampara is a district that has been regarded as strategically important by the Government of Sri Lanka (GoSL) and the Liberation Tigers of Tamil Eelam (LTTE). The GoSL have perceived it as a point where LTTE's penetration could be curtailed. The LTTE, on the other has regarded it as strategic location to penetrate into the interior parts of the government-controlled areas and possibility of making use of it to terrorize the civilians and government forces. The second consideration in choosing this district as the study site was that it is the only district where Tamils have become the second minority ethnic community in the 'Traditional Homeland of Tamils' perceived by the LTTE in the North-Eastern region. The third factor was the necessity of studying hardship faced by the Tamil women who are sandwiched by other cultures and ethnic groups.

This qualitative study was conducted using both primary and secondary data collected from different sources. The primary data gathering for the study took place in two stages. The first phase of data gathering took place from 2007-just before the military defeat of LTTE by the Government forces in 2009. The second phase of data gathering took place in 2016. Multiple data gathering techniques were used taking into consideration that a community that had undergone insurmountable sufferings and sorrow experienced by the women during war in 
the research area. The primary data was collected through direct observation, focus group discussion, and key informant interviews among the selected predominant Tamil villages in the Ampara district. However, no extensive analysis of primary data is incorporated in this paper due to number of reasons.

The secondary data relevant to the study was collected from desk analysis of journal article, book chapters, books, study reports and newspaper articles. The review of the secondary data helped to identify the women role in civil war context and the hardship faced by them. Both primary and secondary data were analyzed with descriptive and interpretive lenses and only the summaries of the major findings are presented in this paper under some thematic topics.

\section{Hardship Faced by Women of Minority Community in War Context: Review of Literature}

The literatures on Sri Lankan civil war have examined the causes of ethnic conflict and civil war. Those literature have come up with different explanations of the causes of the ethnic war. Accordingly, the development policy of the government and exclusion of minorities (Yusoff et al., 2015; Banda \& Abeyrathne, 2004), constitutional making exercises in post-independent political regimes (Uyangoda, 2000), inability of building an integrated political culture (Abeyrathne, 2004), state-crafting issues (Bandara, 2000), electoral politics based greed vs grievances political discourse (Withanawam, 2000), elite formation (Singer, 1964), religion and languages issues (Perera, 2015; Coperahewa, 2009; Kearney, 1967), global and regional geo-political interests (Greg, 1997), economic issues such as unemployment and competition over the limited job opportunities, white collar job oriented education, colonial policy of divide and rule (Samaranayake, 2008) - all are about identifying root causes of the conflict in Sri Lanka.

The scholars that concentrated on the impact of civil war have pointed out the negative consequences such as increasing public spending to maintain a war machine, militarizing of civilian affairs, emergence of totalitarian regimes under the guise of protecting the country by means of war, erosion of democratic values and institutions, spread of socially communicable diseases and the emergence of the unbearable number of differently able people (Biziouras, 2014; De Silva, 2012; CATRD, 2001; National Peace Council, 2001; Edirisuriya, 1999; Amarasinge, 1995; Warnapala, 1994). The other groups of scholars have paid attention to possible ways of transforming the violent conflict to none violent conflict. They have come up with ideas not only of possible political resolution to the conflict but also of failures in the conflict resolution process. The causes for the failures of constitutional arrangement to resolve the conflict is well documented (Bastian, 2013; Wilson, 1988). Still others working with the same traditions have paid attention to the negotiation strategies and their failures (Abeyrathne \& Surendra Kumar, 2014).

Some scholars have paid their attention on the identity crisis and resulting hardship the people had to face in the context of war and assimilative strategies adopted by major conflicting parties (Tangarajah, 2007; Abeyrathne, 2002). The studies conducted in relation to ethnic and communal politics have examined the role of women and how and why they were used to commit violence or military target during war. The women in times of war become 
important in supplying manpower for the war besides women being recruited as combatants of the war. In Sri Lankan context, both government of Sri Lanka and the LTTE had promoted ethnic pride among mothers portraying them as 'Veera Thaai' or 'Veera Maatha' (Meaning Heroine Mother) with the ultimate objective of encouraging women to give sons and daughters to make the ethnic or communal struggle a success.

However, the literature has not adequately studied the hardship faced by women during the war and their continuity even after ending of the war. Few studies have attempted to document the sufferings and hardship faced by women during civil war and war displacement (Brun, 2008; Brun, 2005; Tambiah, 2004). However, the limitations of those studies are that they have not given more attention to the hardship faced by the women of the minority community that have been challenging the political status quo in relation to the situation where the minority has become a minority with other groups. In that context, the hardship faced by these women remain not studied adequately. The objective of the present study is to fill this gap in the present scholarship in relation to Sri Lanka with reference to the situation of Tamil women living in the Ampara district of Sri Lanka.

\section{War Politics and War Hardship}

The concept of war politics remains poorly conceptualized in the literature of political science and conflict resolution. For the purpose of present study, 'war politics' is defined as the emergence of a specific form of politics in time of protracted civil war. Politics can be grouped into two as normal politics and war politics. The distinguishing feature of war politics from that of normal politics is the transformation of political process leading to a breakdown of governmental politics in part or full. The specificity of war politics is that it prevents normal governmental politics and forces it to change routine operational styles. Protracted civil war challenges the power of the state. Consequently, there emerges a dual power system which challenges the sovereignty of the state together with its agent called government. The democratic practices and institutions associated with normal politics such as rule of law, legitimacy of the government, accountability of decision-making and implementing bodies, competitive political party system and pressure group activities, periodical free and fair elections and functioning of healthy civil society organizations are put into jeopardy and are at risk during wars (Imai \& Weinstein, 2000). This situation of breaking down of normal politics requires reinterpretation of governmental politics in the context of war.

As there are little studies on war politics, interpreting war politics has become a daunting task for any student of politics. However, surveying of literature on civil war is helpful in identifying certain features and characteristics inherent in war politics. The literature on civil war had shed light on associated features of war politics which include state crisis, emergence of dual authority system instead of singular authority, militarized politics, repeated internal displacements, culture of violence, coexistence of electoral politics and war politics, war economy etc.

The term 'hardship' denotes a condition that is difficult to endure or in other words, suffering, deprivation and oppression. For this study, the hardship has been defined as 'any kind of 
condition that individual or group of people face suffering, difficulties, worries that challenge their daily affairs. Hardship may be in the form of physical and psychological in nature. People face hardship due to number of reasons, including lack of resources, foods, job opportunities, deprivation of basic needs and rights, denial of and marginalization from accessing public services and utilities. The hardship fall under four broad categories: food insecurity, insufficient access to health care, housing problems, and inadequate child care. A critical hardship in health care occurs when, any individual in the family did not get or postponed necessary medical care. Living without sufficient food is the most basic critical hardship. Critical housing hardship are defined as the consequences of not paying housing bills. Eviction, utility disconnection, and moving in with others because a family could not pay its bills constitute critical housing hardship. Lack of adequate child care is, however, considered a serious hardship because it has long-term consequences for the family's well-being. A serious hardship in child care occurs if the parent experiences the hardship for any child in the household (Heather \& Bethney, 2001). The intense civil war induces almost all four kinds of hardship with other severe impact. Women particularly face serious hardship during and aftermath of civil war.

Modern warfare has had a devastating effect on the lives and dignity of women and girls, as well as on the health and educational services that are essential to family and community survival (UNFPA, 2002). A few decades ago, women and girls in conflict situations were forced to endure brutal incidents of sexual violence, had fewer resources for protection and survival, lost their loved ones and had to take responsibility for their families, were forced to join the combatants, or to flee leaving everything behind. Today, all of these risks are not only just as real, but they are compounded by fact that the very nature of wars invades ever more private spaces, becoming a threat to their identity and security. Added to this, many outbreaks of violence today are of religious or ethnic origin, linked to issues of identity, which play against women and women's rights. Many of these conflicts are marked by extreme violence and gender-based abuse (San Pedro, 2019). Present-day conflicts show that women are increasingly becoming the target of fighting. Women are particularly susceptible to marginalization, poverty and the suffering engendered by armed conflict, especially when they are already victims of discrimination in peacetime (ICRC, 2001). They are also prone to be wounded or killed as legitimate targets. Conversely, women and girls are far more exposed to sexual violence, regardless of the perpetrator's motive, although men are also victims of such violence.

Due to war conditions, women lack the capacity to participate in political or public life and are unable to overcome the stigmas or social pressures that would arise them. In contexts of war, gender inequalities tend to deepen, resulting in a disproportionate impact on women and girls. For them, armed violence implies a double burden: they must endure not only the same atrocities as are visited on all the civilian population, but also existing discrimination and inequalities against women (San Pedro, 2019, p.11). War situation put most of the women in a situation of extreme vulnerability and limited their mobility.

In many conflict situations, war context creating greater devastation amongst women in what is now the largest humanitarian crisis in the world. Extreme poverty and rampant violence 
further affect the security of women and girls. Sexual violence is increasing as a result of the conflict and civil war. Conflicts shape societies at all levels, changing their demographic composition, decimating the population and condemning them to poverty. The financial crisis caused by all situations of armed violence and the loss of men during a war (through injury or death) is spelling out the role of women in the labour market (San Pedro, 2019).

Violence against women increases during conflict situations. Mass rape has often been used as a war tactic to erode individual relations and community and family structures. Increased psychological trauma, unwanted pregnancies from rape and high-risk abortion practices induce further hardships to women. Armed conflicts greatly affect the lives of women and can completely change their role in the family, the community and the 'public' domain. Armed conflicts have created large numbers of female-headed households where the men have been conscripted, detained, displaced, have disappeared or are dead. Women invariably have to bear greater responsibility for their children and their elderly relatives - and often the wider community - when the men in the family have gone.

Violent conflict and civil war induce displacement of civilians. Most of the victims are the women and children. During displacement, women face lot of hardship, as single parent for children and as breadwinner. During displacement and post-war settlement, women face challenges in terms of food insecurity, insufficient access to health care, housing problems, and inadequate child care.

\section{Ethnic Realities and War Impact in Ampara District}

Ampara is one of the noted districts in the North-Eastern region severely affected by the ethnic conflict and prolong civil war in Sri Lanka. The district which was always a part of Kandyan kingdom but was considered as part of the traditional Tamil homeland. The concept of Traditional Tamil homeland for Tamil-speakers has been the basis for Tamils' demand for more autonomy and self-determination in the North-Eastern region where the ethnic Tamils and Tamil-speaking communities, i.e., Tamils and Muslims form the absolute majority.

The position of Amparai district was within the traditional homeland of Tamil is controversial since the majority of the district's population are non-Tamils in terms of ethnicity. The Muslims form the first majority while Sinhalese form the second but on a narrow margin in terms of number. The Tamils forms the second minority ethnic group in the Ampara district which make the Tamils in vulnerable position within the territory of the wider traditional Tamils' homeland. However, the noteworthy fact is that no ethnic community can override the other ethnic groups in this district unlike the rest of the districts in the country. Table 1 presents the ethnic composition of the population of the district. 
Table 1. Population of Amparai District by Ethnic Group (1963-2012)

\begin{tabular}{llllllllll}
\hline \multirow{2}{*}{$\begin{array}{l}\text { Census } \\
\text { Year }\end{array}$} & \multicolumn{2}{l}{ SL Muslims } & \multicolumn{2}{l}{ Sinhalese } & \multicolumn{3}{l}{ SL Tamils } & \multicolumn{3}{c}{ Others } & \multirow{2}{*}{ Total } \\
\cline { 2 - 8 } & No & $\%$ & No & $\%$ & No & $\%$ & No & $\%$ & \\
\hline 1963 & 97,621 & 46.11 & 61,996 & 29.28 & 49,185 & 23.23 & 2,930 & 1.38 & 211,732 \\
1971 & 126,365 & 46.35 & 82,280 & 30.18 & 60,519 & 22.20 & 3,441 & 1.26 & 272,605 \\
1981 & 161,568 & 41.45 & 146,943 & 37.78 & 77,826 & 20.01 & 2.633 & 0.67 & 388,970 \\
2012 & 281,702 & 43.38 & 252,458 & 38.88 & 112,457 & 17.31 & 2,785 & 0.43 & 649,402 \\
\hline
\end{tabular}

Source: Department of Census and Statistics 2007 \& 2014.

The above table clearly shows that the Muslims form the numerical majority of the population of the district. In the course of time, Sinhalese were able to increase their presence in the area due to the state-sponsored settlement schemes of the central government in the area. However, the above statistics obscures the ontological reality of multiculredness of the district. There are differences among the Muslims in terms of religious sects. The Sinhalese have also got significant differences in terms of traditional villagers and the people living in government-sponsored colonization schemes. The category of Tamil includes Sri Lankan Tamils as well as Tamils of Indian origin. The Muslims have found their habitat mostly in coastal areas of the district. The areas where Muslims form the majority, such as Kalmunai, Sainthamaruthu, Nintavur, Addalaichchenai, Akkaraippatthu and Sammanthurai show a high level of population density. Unlike the Muslims in the rest of the country, Muslims of Ampara district share many things with the peasantry of either Tamil or Sinhalese for they depend heavily on agriculture and fishing in meeting their means of living (Note 1). The population density has increased group sentiments among them.

The Tamils of the district are basically concentrated in areas of Tirukkovil, Aliyadivembu, Navidanveli, Karaitivu and Kalmunai. They have been living in those areas for generations. Their main means of living has been either agriculture or fishing. What was observable of them was the lack of their own political leadership. The social norm of caste value has been more prevalent among them. The official records in the parliament and other means of communication revealed that their economic and social wellbeing remained less visible in the policy-making deliberation. One of the reasons for this situation has to do with political leadership that was provided for them by the Northern elite. They have been less vocal on issues of economic grievances for ethnicity worked as the over-determining factor of politics among Tamils since the introduction of territorial-based electoral system since 1931 (Wilson, 1975). In this cultural context, they are a minority among the minority in Sri Lankan politics and can be regarded as the innocent of the innocent. During field survey for the study, the villagers expressed that they would not find any solution to their problems because neither Sinhalese political leadership nor Muslim political leadership was keen on addressing their issues in the culturally segregated political setup. According to their explanation, the mainstream Tamil political leadership opted to sit in the opposition camp as a habit. 
Initially, Ampara was a part of the Batticaloa district. It was carved out of Southern part of that district. The debates in the national parliament revealed there were ethnic politics behind the carving out of this particular administrative district (Hansard 1961, 7 April). The minorities perceived the move of the government as an attempt to reduce the numerical strength of the Tamils of Eastern province and their presence in the national parliament. The argument was based on the point that it was a systematic administrative and political step taken by the Sinhalese government to curb and contain the traditional homeland of the Tamil-speaking community. Yet the Muslims' perception was somewhat different. Though they speak Tamil language and share many cultural aspects in common with that of the Tamil community, they have opposed the assimilation strategy adopted by Tamil political elites. They perceived of themselves as a distinct identity groups having their own culture. They did not oppose the idea of a separate administrative unit but over the location of the administrative headquarter of the district (Hansard 1961, 6 April). They wanted it to be located in Muslim majority area of Akkaraipattu or Kalmunai. The rationale of having such an idea was a cultural one. They pointed out, that if the administrative headquarters of the district was located in a Sinhalese majority area, the womenfolk of their community will have to venture out of their cultural habitat and it would damage their culture in different ways (See: Sarjoon et al., 2015). On the other hand, the Sinhalese dominated government had engaged in colonization schemes with different purposes. However, the annexing parts of Moneragala and Polonnaruwa districts with the newly formed Ampara district in different phases were politically motivated and aimed at diminishing the Tamils dominancy in the Eastern province. For whatever reason, the district now has become a multi-cultural and diverse district in Sri Lanka. The cumulative effect of the politico-administrative decision of making Ampara was, the becoming Tamils the lowest minority group in the new set-up.

The people of the Ampara district have experienced the bitter life experiences of civil war based on ethnicity as LTTE had been present in the area since 1990s. The departure of Indian Peace Keeping Force (IPKF) and the defeat of opposing militant Tamil groups by the LTTE had paved the way for the LTTE to become the dominant military group in the area. Therefore, it became the sole anti-government militant group in the district. One of the characteristic features of the LTTE carders has been the inclination to the idea of a separate Tamil Eelam State at whatever cost. The LTTE perceived Ampara as strategically important for the Tamils in the district which juxtaposed the Tamil majority district of Batticaloa and costal belt of the Eastern sea of the country which made access possible to the militant Tamil groups dominated in the North-Eastern region in the country. It is worth noting that about 45 percent of the land of the Ampara district is covered by forest and it provided a safe haven for guerrilla warfare strategy of the organization. In fact, the LTTE had maintained training camps and military bases in the forest area of the district.

In addition to the above facts, the Ampara district has borders with five provinces of the country. According to the LTTE perception, this particular situation gives a strategic significance to its terror tactics of ambush attach on the military as well as civilians of government-controlled areas. Increased military operation of LTTE in the districts had compelled the government to deploy its forces including police to be present everywhere in 
the areas of the district. The government also thought it was an utmost necessity to protect Ampara district at whatever cost, for protecting it implied curbing the military penetration by the LTTE and establishing a military base from where it could operate to defeat the LTTE and regain the areas under the LTTE's control.

The other specific feature of the war was that neither party was able to control the total area of the Ampara district implying insurmountable suffering for the civilians. Since the LTTE was unable to establish a permanent area under their control in the district, one would not find any of the shadow state apparatus such as court and police run by the LTTE unlike other districts of Northern and Eastern provinces of the country.

\section{War Hardship of Tamil Women in Ampara District}

The above explained elements or characteristics of war politics in Sri Lanka is closely linked with the hardship faced by the women of minority Tamils of the Ampara district and they are interrelated. The state crisis situation under the civil war has contributed to the hardship that the women have to face. In a crisis situation, the government faced the problem of maintaining law and order because there was a challenge to the legitimacy of the state apparatus in many and varied ways. The rule of law principle became irrelevant with the crisis of the state. The rule of law had got supplemented by the dictate of the military warlords of the government and militant groups. In that situation, people of the area faced the problem of choosing to which authority they should obey and become obedient. Military operations were constant in search of militant guerillas of the LTTE. It was women who were constantly interrogated by military personnel in the day time. In the night time, it was guerilla that questioned women about the military operations and they become suspects of spying for both parties and had to face intolerable hardship in answering the queries posed by both parties, particularly in the Hindu cultural milieu. Further, state crisis also affected the welfare dimensions of women in many ways. As a norm in Sri Lanka, it was the state that provides maternity care and medical care for pregnant women. The crisis of state had denied them reaping those social benefits provided by the state for the facilities in Tamil majority areas of the Ampara district became inaccessible due to presence of LTTE and suspicion of their presence.

The war situation based on ethnicity and protracted civil war resulted in an emergence of dual authority system, i.e., one formal and the other informal authority in the governance process of the country. The formal authority system included the government machinery of Sri Lanka and the informal authority system included the military leaders of the LTTE and their shadow state apparatus including courts, police and civilian administration carried out in tandem with that of the government of Sri Lanka. In most of the cases, the officers recruited by the government and paid by the government had to operate not according to the rules and regulations of the government but according to the dictates of the LTTE leaders of the area. This had resulted in excluding some Tamils as beneficiaries of social welfare programmes of the government while excluding some families from the said programme on assumption of loyalty to the organization. However, it was the women who had to undergo the hardship created by such exclusion. 
The civilian administrative arm of the government in providing basic facilities for the citizens was replaced by the military personnel in the context of militarized politics. The male of young age were attracted by militant groups voluntarily or forcefully. Even female had been forcefully abducted and made combatants of the militant group. The cumulative effect was unbearable hardship upon the womenfolk of the minority groups. The possible way of protecting the girls was to arrange marriages for them prematurely. The issue was matching partners who were not available and consequently male and female were made to enter into marriages without means of sustaining a household life and without any experience in the social milieu of family life.

In many Tamil predominant villages in the Ampara district, there were instances where males were forcefully recruited to the arm wing of the gorilla organizations even though they were already married. In Such instances, the female became a prey of sexual exploitation by various parties. It was also noticed during the field survey, that there was a considerable number of women of young age who were arranged to marry elderly persons. As law and order were not in place under war politics, many of the marriages were not properly registered. This made it easy for the male to escape from family responsibilities and an emergence of a social category of disserted women among the minority community even to date. In certain instances, the war between conflicting parties resulted in deaths of male partner. The women found parental home as the only place for survival and burdening the elderly parents.

There were other issues particularly related to ex-combatant female among the Tamil community in the Ampara district. The female partners who joined the military arm of the LTTE during war were highly regarded as heroines that destroyed the villain enemy, i.e. Sinhalese military. However, with end of civil war, they became the focal point of disgrace in the Tamil Hindu cultural context. They are treated improper for marriages for they had spent nights in military camps with males and their virginity was questionable. Consequently, they found it extremely difficult to find a partner to enter into a marriage and spend conjugal family life.

The war also resulted in a series of internal displacement in the context of violent conflict from place to place in the district. That meant loss of means of livelihood. Loss of livelihood badly affected the women in particular. The meager salary the male partners earned was not sufficient to survive at all and they used to spend a big share of earning for their own leisure activities such as consuming alcohol etc. from their temporary employments. This situation had compelled the women to go out of temporary shelters in search of extra income for the family. In this process, they underwent insurmountable hardship including sexual exploitation.

\section{Concluding Remarks}

This study has attempted to explore the hardship faced by the women of the minority Tamil community in the Ampara district in the Eastern province of Sri Lanka in the context of war politics during civil war. The study has found that the intense civil war and war politics have induced the women of Tamil community in the district to undergo suffering and hardship in 
different ways. The hardship and suffering faced by women of the minority community was higher than that of the male in the context of civil war. The women faced specific problems in the war context. The war has given birth to a social category of war widows which is a continuing problem even after the end of the civil war. It implies that the policy-makers need to pay special attention in developing welfare policies to take care of this category of women and widow headed families. In addition to the above, the ex-combatant women found it difficult to live in the patriarchal society of Hindu culture. This meant that government and other stakeholders need to pay special attention to ease the norms of the culture through special education programmes etc. The break of law and order has resulted in pre-mature marriages of girls and boys of the community as a strategy of escaping getting recruited into the militant arm wings of the LTTE. Because marriages were not registered, the women were disserted with children. These issues continue even after the war. In a meaningful reconciliation process these issues need to be given special attention by policy-makers and other actors involving in the post-war development and reconciliation process.

\section{Acknowledgement}

This study was conducted using author's self-fund. The author expresses the gratitude to those assisted in preparing the manuscript. Author also declares no conflict of interest in the content of the paper.

\section{References}

Abeyrathne, G. D. R. U. U., \& Surendra, K. S. Y. (2014). Sri Lankan ethnic crisis. In S. Varkey (Ed.), Globalization, state and governance. New Delhi: New Century Publication.

Abeyrathne, U. (2002). Ethnic war and traditional status in an ethnically mixed community: A study of Panama on the east coast of Sri Lanka. Retrieved from https://www.anthro.ox.ac.uk/sites/default/files/anthro/...jaso4_1_2012_55_73.pdf

Abeyrathne, U. (2004). Ethnic problem and Sri Lankan political culture. In F. George \& B. Klem (Eds.), Dealing with diversity: Sri Lankan discourses on peace and conflict (pp. 87-99). Clingendael: The Netherlands Institute of International Relations.

Amaransinge, Y. R. (1995). Aspects of the state crisis in Sri Lanka. In M. Werake \& P. V. J. Jayasekara (Eds.), Security dilemma of a small state (part 2, pp. 69-90). New Delhi: South Asian Publishers Pvt. Ltd.

Banda, R., \& Abeyrathne, U. (2004). Perspective from the south. In F. Georg \& B. Klem (Eds.), Dealing with diversity: Sri Lankan discourses on peace and conflict (pp. 45-66). Clingendael: The Netherlands Institute of International Relations.

Bastian, S. (2013). Post-colonial Sri Lankan state: The rural sinhalese society and the ethno-political conflict. In J. Uyangoda (Ed.), State reform in Sri Lanka: Issues, direction and perspectives (pp. 189-238). Colombo: Social Scientist Association.

Biziouras, N. (2014). Political economy of Sri Lankan ethnic conflict. London, Routledge.

Brun, C. (2005). Women in the local/global fields of war and displacement in Sri Lanka. 
Gender, Technology and Development, 9(1), 57-80.

Brun, C. (2008). Finding a place: Local integration and protracted displacement in Sri Lanka. Colombo: Social Scientist Association.

CATRD (Center for Advanced Training in Rural Development). (2001). Conflict: Treat or opportunities? Land use and coping strategies of war affected communities in Trincomalee, Sri Lanka. Berlin: Margraf and Verlag.

Coperahewa, S. (2009). The language planning situation in Sri Lanka. Language Planning, 10(1), 69-150.

De Silva, K. M. (2012). Sri Lanka and the defeat of the LTTE. Colombo: Vijitha Yappa Publication.

Department of Census and Statistics. (2007). Special enumeration-eastern province 2007. Colombo: Department of Census and Statistics.

Department of Census and Statistics. (2014). Census of population and housing-2012 (New) Final report. Colombo: Department of Census and Statistics.

District Secretariat. (2005) District statistical information handbook. Ampara: District Planning Secretariat.

Edirisuriya, P. (1999). Determinants of military expenditure in Sri Lanka. In S. Gamage \& I. B. Watson (Eds.), Conflict and community in contemporary Sri Lanka (pp. 229-239). New Delhi: Sage Publication.

Greg, A. (1997). Economic liberalization and separatist's nationalism: The case of Sri Lanka and Tibet. International Affairs, 51(1), 117-146.

Heather, B., \& Bethney, G. (2001). When work just isn't enough: Measuring hardships faced by families after moving from welfare to work. Washington, DC: Economic Policy Institute.

Imai, K., \& Weinstein, J. (2000). Measuring the economic impact of civil war. CID Working Paper, no.15, Centre for International Development at Harvard University, Retrieved from http://imai.princeton.edu/research/files/cid.pdf.

International Committee of Red Cross (ICRC). (2001). Women facing war. Geneva: International Committee of Red Cross.

National Peace Council. (2001). Economic, social and human cost of the war in Sri Lanka. Colombo: National Peace Council.

Navaratna, B. A. M. (2000). Ethnic relations and state crafting in post-independence Sri Lanka. In W. D. Laksman \& C. A. Tisdell (Eds.), Sri Lanka's development since independence: Socio-economic perspectives and analyses (pp. 113-126). New York: Nova Science Publishers Inc.

Perera, S. (2015). Reflections on issues of language in Sri Lanka: power exclusion and inclusion. In H. Coleman (Ed.), Language and social cohesion in the developing world (pp. 


\section{Macrothink \\ International Journal of Social Science Research \\ ISSN 2327-5510 \\ 2021, Vol. 9, No. 2}

55-74). Colombo: British Council.

Samaranayake, G. (2008). Political violence in Sri Lanka in 1971-1987. New Delhi: Gyan Publishing House.

San Pedro, P. (2019). Women in conflict zones. Oxfam Intermón. Report. No.51. Retrieved from

https://oxfamilibrary.openrepository.com/bitstream/handle/10546/620690/bp-women-in-confl ict-zones-290319-en.pdf

Sarjoon, A., Yusoff, M. A, Hussin, N., \& Awang, A. (2015). The demand for an administrative district for the coastal belt of Amparai district in Sri Lanka: An assessment of its root causes. Mediterranean Journal of Social Sciences, 6(4S3), 434-443.

Singer, M. (1964). The emerging elite: A study of political leadership in Ceylon. Cambridge: MIT Press.

Tambiah, Y. (2004). Sexuality and women's rights in armed conflict in Sri Lanka. Reproductive Health Matters, 12(23), 78-87.

Tangarajah, Y. (2007). Sri Lankave veralaveda veddange hanipatbava pilibanda akhyana Janavargika Ananyatavalesa. In S. Perera \& H. Dasanayake (Eds.), Sri Lankeve Samajaya ha Sanskrutiya Patanaya kirima: Torangi, (devana veluma) (pp. 48-83). Colombo.

UNFPA (United Nations Population Fund). (2002). The impact of armed conflict on women and girls: Consultative meeting on mainstreaming gender in areas of conflict and reconstruction. Retrieved from https://www.unfpa.org/sites/default/files/pub-pdf/impact_conflict_women.pdf

Uyanngoda, J. (2000). Post-independence social movements. In W. D. Laksman \& C. A. Tisdell (Eds.), Sri Lanka's development since independence: Socio-economic perspectives and analyses (pp. 61-76). New York: Nova Science Publishers Inc.

Warnapala, W. (1994). Ethnic strife and politics in Sri Lanka: An investigation in to demands and responses. New Delhi: Navrang.

Wilson, A. J. (1975). Electoral politics in an emergent state: The Ceylon general election of May 1970. London: Cambridge University Press.

Wilson, A. J. (1988). The break-up of Sri Lanka: The Sinhalese Tamil conflict. London: Hurst.

Witanawasam, A. (2000). Electoral administration and political violence in Sri Lanka. Unpublished M.A. Thesis, University of Peradeniya, Peradeniya, Sri Lanka.

Yusoff, M. A., Sarjoon, A., Awang, A., \& Handi, I. H. (2015). Land policies, land-based development programs and the question of minority rights in Eastern Sri Lanka. Journal of Sustainable Development, 8(8), 223-233. 
Notes

Note 1. There are a small number of descendants of the Vedda community, but they had embraced the cultural artifacts of the traditional Sinhalese villagers and cannot be distinguished anymore.

\section{Copyrights}

Copyright for this article is retained by the author(s), with first publication rights granted to the journal.

This is an open-access article distributed under the terms and conditions of the Creative Commons Attribution license (http://creativecommons.org/licenses/by/4.0/). 